PLANT

SCIENCE

\section{The diversity of fatty acid composition in traditional and rare oil crops cultivated in Russia}

\author{
Vera Gavrilova, Tatyana Shelenga, Elizaveta Porokhovinova, \\ Aleksandra Dubovskaya, Nina Kon'kova, Sergey Grigoryev, \\ Larisa Podolnaya, Aleksey Konarev, Tamara Yakusheva, \\ Natalya Kishlyan, Andrey Pavlov, and Nina Brutch
}

Federal Research Center N. I. Vavilov All-Russian Institute of Plant Genetic Resources, Bol'shaya Morskaya ul., 42-44, Saint Petersburg, 190000, Russian Federation

Address correspondence and requests for materials to Nina Brutch, n.brutch@vir.nw.ru

\section{Abstract}

This review is devoted to the description of chemical peculiarities of industrial oil crops cultivated (or prospective for cultivation) in Russia, which are stored in the VIR collection. Different crops have similar fatty acids biosynthesis pathways, but each species has its own individualities in the chemical composition of the oil and its genetic control. The diversity of oil crop chemical composition opens the possibility of its multipurpose utilization practically in all industrial segments. Sunflower, rapeseed, flax, mustard, camelina and safflower are cultivated in Russia as oil crops. Castor beans, perilla, lallemantia and noog are not cultivated on an industrial scale, but have original oil properties and are prospective for future cultivation. Hemp and poppy seeds contain oil valuable for food, but they are not widespread. Cotton and peanut oils are prospective for industrial purposes when early, already created varieties of these crops will be cultivated in Russia. Oil properties depend on the ratio of its basic fatty acids: saturated (stearic, palmitic) and unsaturated (oleic, linoleic, linolenic). As a rule, lauric, myristic and palmitoleic acids are determined in minor quantities. The oil of Brassicaceae crops also includes arachidic, eicosenoic, eicosadienoic, behenic, erucic and lignoceric acids. Fatty acids accumulation is influenced by growing conditions, though it has strict genetic control.

Keywords: oil crops, fatty acids, sunflower, linseed, rapeseed, safflower, mustard, castor bean, hemp, peanut.

\section{Introduction}

Until the second half of the 19th century, flax and hemp were the main oil crops in Russia. Fibre from the stems of these plants was widely used for tissues, ropes and burlap, and edible oil was pressed from the seeds. Confectionery was prepared on the basis of poppy oil. For lighting (burning torches), rapeseed and colza (Brassica campestris) oils were used. In the Volga region (Volgograd, Astrakhan region) brown mustard (Brassica juncea), which is one of the main oilseeds in the East (in India and Southeast Asia), was cultivated. Archaeological excavations have shown that in ancient times one of the main oilseeds of the Far East was perilla. Perilla oil hitherto was used in Korea. In 1862 in Alekseevka (Belgorod region) the industrial method of sunflower oil production from seeds was invented. This oil appeared to be tastier than the others and was widespread. Now, sunflower, rapeseed, flax, mustard and safflower are cultivated in Russia. Hemp - the old Russian crop - is restricted to the cultivation of varieties lacking tetrahydrocannabinol. Until 2016 castor bean production was maintained. At the same time, now the growing area of camelina - a very early maturing crop, with a wide area of growth, resistant to salinization, many pests of cabbage crops and other adverse environmental factors - is increasing. The yield of most of these crops in the best 
years reaches 10-15 t/ha (FAOSTAT, 2019). Mustard and safflower give up to $7 \mathrm{t} / \mathrm{ha}$, and hemp gives up to $5 \mathrm{t} /$ ha. Cotton is not cultivated now as an oil crop, but it is a strategically important crop. Promising crops for future cultivation are: noog, perilla, lallemantia, crambe and eruca. The yield of their seeds does not exceed $1 \mathrm{t} / \mathrm{ha}$.

The collection of the VIR Department of Genetic Resources of oilseeds and fibre crops maintains about 29,700 living accessions, including 11,500 oilseeds (sunflower, oilseed cabbage crops, castor beans, rare oilseeds), 16,500 double-use crops (flax, hemp, cotton) and about 700 accessions for industrial purposes only. Most folk-bred oilseed varieties contain $33-40 \%$ oil in seeds. As a result of breeders' work, high-oil sunflower varieties were created, containing up to $56 \%$ oil in seeds (and up to $60 \%$ oil in the kernel); up to $45-53 \%$ oil in flax seeds; $45-48 \%$ oil in rapeseed; $50-60 \%$ oil in peanuts; $33-39 \%$ oil in safflower (in the kernel - up to $50-56 \%$ ). The main components of oils are fatty acid triglycerides. The oil properties are determined mainly by the ratio of saturated (stearic and palmitic) and unsaturated (oleic, linoleic, linolenic) fatty acids. These fatty acids are contained in oil that is considered edible. Oil containing a high amount of long-chain acids (over 22 carbon atoms) is suitable only for industrial use.

In the process of fatty acid synthesis, the elongation of the carbon chain is influenced by two synthetases, which are complex enzyme systems. One of the synthetases extends the carbon chain from $\mathrm{C}_{16}$ to $\mathrm{C}_{18}$. The other synthetase extends the carbon chain from $\mathrm{C}_{18}$ to $\mathrm{C}_{30}$. The formation of double bonds occurs under the control of the desaturase enzyme system. Oleic $\left(\mathrm{C}_{18: 1}\right)$ and erucic $\left(\mathrm{C}_{22: 1}\right)$ acids contain one double bond. Two double bonds are characteristic of linoleic acid $\left(\mathrm{C}_{18: 2}\right)$. Linolenic acid $\left(\mathrm{C}_{18: 3}\right)$ has three double bonds. The action of elongase and desaturase in linolenic acid leads to the formation of arachidonic acid $\left(\mathrm{C}_{20: 4}\right)$, which has four double bonds (Krasilnikova et al., 2004).

The most detailed principle scheme of fatty acids biosynthesis and its genetic control was developed using the model plant Arabidopsis thaliana (Ohlrogge and Browse, 1995; Schmid, 2016). The substrate for the synthesis of saturated stearic acid $\left(\mathrm{C}_{16: 0}\right)$ is AcetylCoA, which is modified by a multi-enzyme complex. The elongation of the carbon chain to 18 atoms to form palmitic acid $\left(\mathrm{C}_{18: 0}\right)$ occurs under the action of the gene FAB1 (Fatty Acid Biosynthesis 1). The FAB2 gene, encoding the desaturase enzyme, is responsible for the formation of oleic acid $\left(\mathrm{C}_{18: 1}\right)$. Two genes, FAD (Fatty Acid Desaturase): FAD2 $\left(\mathrm{C}_{18: 1} \rightarrow \mathrm{C}_{18: 2)}\right.$ and FAD3 $\left(\mathrm{C}_{18: 2} \rightarrow \mathrm{C}_{18: 3}\right)$, are responsible for the desaturation of non-chloroplast lipids in Arabidopsis, and chloroplast lipids desaturation is controlled by five genes: FAD4 and FAD $5\left(\mathrm{C}_{16: 0} \rightarrow \mathrm{C}_{16: 1}\right)$, FAD6 $\left(\mathrm{C}_{18: 1} \rightarrow \mathrm{C}_{18: 2}\right)$, FAD7 and FAD8 $\left(\mathrm{C}_{18: 2} \rightarrow \mathrm{C}_{18: 3}\right)$. However, different plants have their own characteristics of fatty acid composition and peculiarities of its genetic control.

\section{Industrial crops for oil production}

Sunflower (Helianthus annuus L. family Asteraceae). The best sunflower varieties of traditional use for oil have the following fatty acid composition: $1.0 \%$ stearic acid, $1.2 \%$ palmitic acid, $10.8 \%$ oleic acid, $70.0 \%$ linoleic acid, and $1.0 \%$ linolenic acid (Tab. 1). Modern devices and methods of evaluation make it possible to expand the range of quantitative evaluation of fatty acids in oil. A. Chernova et al. (2019) presented data on the content of 11 fatty acids $\left(\mathrm{C}_{12}-\mathrm{C}_{24}\right)$ in oil. However, the percentage content of the minor acids ranging in the interval of $0.002 \%-0.003 \%$ has no effect on the qualitative characteristics of sunflower oil (Demurin et al., 2016). Mutants with a high content of palmitic acid up to $25 \%$ (PerezVich, 2002) or with a high content of stearic acid ( 25\%) (Fernandez-Martinez et al., 2004, 2007) were created. It was supposed that the high content of palmitic acid in sunflower oil is controlled by several recessive alleles: one in the line 275HP (Ivanov et al., 1988) and three in the line CAS-5 (Perez-Vich et al., 2002). One recessive allele Es (Perez-Vich et al., 2006.) controls the high content of stearic acid in the CAS-14 line.

With the help of chemical mutagenesis K. I. Soldatov et al. (1976) obtained a mutant sunflower form with an oleic acid content of about $70 \%$. The increased content of oleic acid prevents rancidity of the oil, which is essential for storage and is of special importance for the canning industry. This amount of oleic acid is controlled by a single dominant $O L$ gene (Demurin and Borisenko, 2011). The presence of modifying genes in the genotype increases the content of oleic acid up to $80 \%$ and even $90 \%$ (Miller et al., 1987). Other authors consider that the trait of high oleic acid content is determined by three dominant complementary genes (Fernandes-Martines, 1989; Perez-Vich, 2002) or five OL genes (Velasco et al., 2000). It was later shown that the increased content of oleic acid correlates with the expression of the gene FAD2-1, which determines the synthesis of the desaturase enzyme and conversion of oleic acid to linoleic (Schuppert et al., 2006). Most likely, evaluation of the inheritance of genes controlling the synthesis of desaturase enzymes will help to understand the genetic control of fatty acids in the sunflower. Over time, it turned out that more balanced oil with a medium amount of oleic acid is more practical. Thus, a line with $69 \%$ oleic acid in oil was created (Demurin et al., 2016).

Safflower (Carhtamus tinctorius L. family Asteraceae). Safflower is widely used as an oilseed, colorant and fodder crop. Seeds contain 35-50\% oil and 15-20\% protein. Safflower oil differs from sunflower oil in fatty acid composition, but its taste is softer and more neu- 


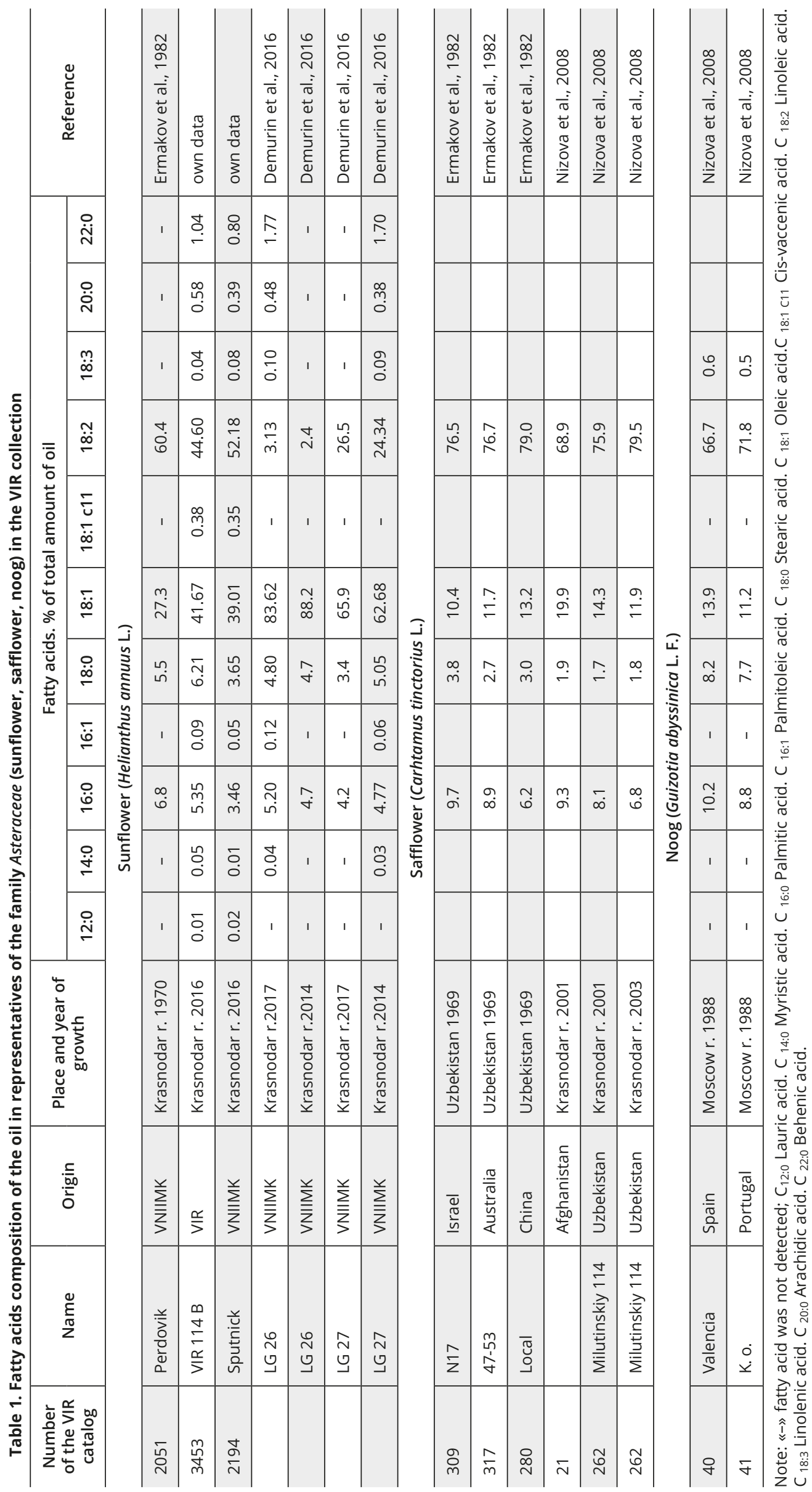


tral. Safflower oil can contain up to $88.3 \%$ linoleic acid, $19.9 \%$ oleic acid, $9.3 \%$ palmitic acid, $2.3 \%$ stearic acid and $0.2 \%$ linolenic acid (Minkevich, 1939). The high content of essential linoleic acid in the oil makes safflower oil valuable for nutrition (Tab. 1). Safflower is also an unpretentious oilseed due to the fact that it can be grown in the arid conditions of steppe regions, which allows farmers to make a profit without the use of complex farming techniques. It was shown that the composition of fatty acids in safflower oil is affected by the genotype and the place of cultivation, but the most important factor is the temperature. Higher temperatures contribute to higher contents of oleic acid, but a lower amount of linoleic acid (Dergisi, 2007).

In India in 1957, a safflower line was isolated with oil containing $64-83 \%$ oleic acid and $12-13 \%$ linoleic acid. Knowles and Hill (1964) conducted a hybridological analysis and found out that the ratio between oleic and linoleic acids was regulated by the main locus of the $O L$ gene. The OLOL genotype determined the synthesis of $72-80 \%$ linoleic acid in oil, and olol controlled the increased content of oleic acid (72-80 \%). In 1964 in Palestine, a safflower line was found with seed oil containing about $43 \%$ oleic acid, but it had in its genotype neither $O L O L$ nor olol. Genetic analysis showed that the portion of oleic acid in the seed oil of this line was determined by one allele, $o l^{1}$, which is located in the same locus as the alleles $O L$ and $o l$, while the genotypes $o l^{1} o l^{1}$ and $\mathrm{OLol}^{1}$ provided approximately equal amounts of oleic and linoleic acids (Knowles et al., 1964, 1965; Burkhardt et al., 1971). In 1989, the authors reported that OLOL and olol genotypes were more tolerant to temperature changes than the $o l^{1}$ gene. At the highest temperature in the genotypes $\mathrm{ol}^{1} \mathrm{ol}^{1}$ and $\mathrm{OLol}$ linoleic acid content was slightly reduced, and that of oleic acid was proportionally increased (Knowles, 1989; Liu et al., 2016).

Mutants with a high content of stearic acid (5-12\%) were found among accessions from Israel and Russia. They had the same mutations at the st locus, which was independent of the ol gene (Ladd and Knowles, 1970, 1971). A safflower mutant was found in Portugal with linoleic acid contents in oil between 85 and $90 \%$, which was $10 \%$ higher than the standard high linoleic type. The levels of all other fatty acids were reduced. This phenotype was controlled by the gene $l i$, different from the loci ol and st (Futehally, 1982).

Later, in safflower an unusual large family of FAD2 genes was also found (Cao et al., 2013). CtFAD2-1 and CtFAD2-10 are encoding oleic acid desaturases, specific for the ripening seeds and flowerhead, respectively. CtFAD2-5 and CtFAD2-8 are expressed in root tissues, while CtFAD2-3, 4, 6, 7 are common mainly for cotyledons and hypocotyl of young safflower seedlings. It was found that CtFAD2-9 encodes a new desaturase running on substrate $\mathrm{C}_{16: 1}$. CtFAD2-11 is a three- functional enzyme capable of a double bond formation between carbon atoms in the cis or trans configuration, or a triple (acetylene) bond between carbon atoms in oleic acid, which converts it to linoleic acid. The authors believe that these 11 FAD2 genes are not allelic and probably have evolved through gene duplication at several hierarchical levels (Cao et al., 2013).

Noog (Guizotia abyssinica L. family Asteraceae). The oil content of noog seeds in different accessions of the VIR collection ranges from 37 to $44 \%$. It can contain up to $71.8 \%$ linoleic acid, $13.9 \%$ oleic acid, $10.2 \%$ palmitic acid, $8.2 \%$ stearic acid and $0.6 \%$ linolenic acid (Tab. 1). Noog oil is characterized by the predominance of linoleic acid and a nutty flavor.

Rapeseed (Brassica napus (L.) subsp. oleifera Metzg. family Brassicaceae). Rapeseed oil includes fatty acids with carbon atom chains of 12 to 24 , among which are saturated, monounsaturated and polyunsaturated acids (Tab. 2). Many acids are synthesized in an amount of less than $1 \%$ of total oil volume, and about $95 \%$ of oil is formed by palmitic $\left(\mathrm{C}_{16: 0}\right)$, oleic $\left(\mathrm{C}_{18: 1}\right)$, linoleic $\left(\mathrm{C}_{18: 2}\right)$, linolenic $\left(\mathrm{C}_{18: 3}\right)$, gondoinic or cis-11-eicosenoic $\left(\mathrm{C}_{20: 1}\right)$ and erucic $\left(\mathrm{C}_{22: 1}\right)$ acids. Among the long-chain acids the most abundant one is monounsaturated erucic acid, which is not digested by mammalian enzyme systems. Without breeding aimed at specific oil fatty acid composition, the erucic acid content may vary widely, for example, from $13 \%$ in the Fedorovsky variety (k$4680)$ to $51 \%$ in the Snitynsky variety (k-4688) (Nizova et al., 1999).

In the 1960s, Canadian researchers found a rapeseed mutant that does not contain erucic acid in its oil (Stefansson et al., 1961). Modern agricultural standards in Russia allow the content of erucic acid to make up no more than $5 \%$ of rapeseed oil used for food purposes (GOST 31759-2012), but in reality, the released varieties contain less than $1 \%$ erucic acid. The initial breeding lines do not form erucic acid, but in industrial cultivation of the varieties and hybrids of rapeseed, a certain amount of erucic acid is synthesized. Erucic acid synthesis is controlled by two genes with five alleles for each one. Recessive allele $e$ determines the synthesis of less than $1 \%$ erucic acid in the total amount of oil, $E^{a}$ forms $10 \%$ erucic acid, $E^{b}-15 \%$ erucic acid, $E^{c}-30 \%$ erucic acid, $E^{d}-3.5 \%$ erucic acid (Krzymanski and Downey, 1969).

Oil of varieties with a high content of erucic and eicosene fatty acids (55-60\%) is considered to be industrial and is used for the manufacturing of varnishes, paints, lubricants, in the production of polymers and synthetic fabrics, in the soap and perfume industry, for the production of methyl alcohol and as diesel fuel (Gavrilova et al., 2005a, b). With a decrease in the erucic acid content in the oil, oleic acid is accumulated up to $60-65 \%$ (Tab. 2). It brings rapeseed oil quality close to 


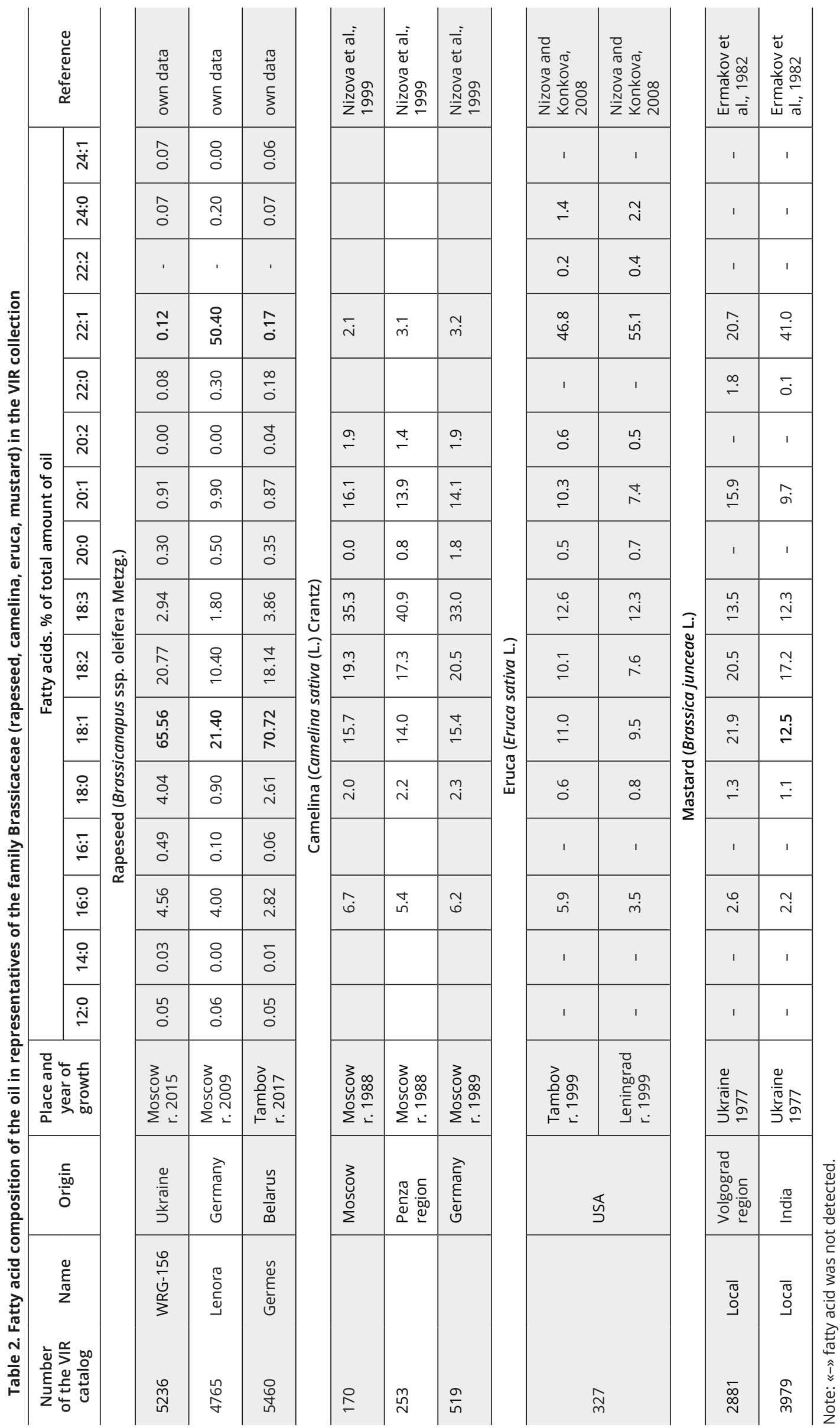


that of olive oil. Increasing the oleic acid proportion is the goal of many breeding groups. For example, breeders of the Russian Research Institute of Oil Crops, using the method of chemical mutagenesis, have created a variety of spring rape, Amulet, with $77.5 \%$ oleic acid in the oil (Gorlov et al., 2015).

Canadian scientists have increased the content of oleic acid in rapeseed oil to a level significantly higher than that of existing varieties. Their work confirmed the exact number of alleles of the FAD2 gene found in B. napus. By detailed genetic analyses and sequencing, they have found that there are four alleles of the FAD2 gene in the rapeseed genotype. By combining the properties of each individual fad 2 allele, they formed the optimal combination of alleles for the creation of new rapeseed lines with oleic acid content increased up to $86 \%$ (Nath et al., 2016). The use of traditional breeding approaches and biotechnological methods made it possible to increase oleic acid in rapeseed up to $89 \%$ (Sakhno, 2010).

In rapeseed it was found that the synthesis of linolenic acid can occur two different ways: by direct desaturation of oleic acid $\left(\mathrm{C}_{18: 1}\right)$ forming linoleic acid $\left(\mathrm{C}_{18: 2}\right)$ and then producing alpha-linolenic acid $\left(\mathrm{C}_{18: 3}\right)$, or by desaturation of short-chain acid with 12 carbon atoms followed by the elongation of the carbon chain $\left(\mathrm{C}_{16: 3}\right.$ and then $C_{18: 3}$ ) (Brar and Thies, 1978). The ratio of linoleic and linolenic fatty acids is controlled by the FAD3 gene (Bocianowski et al., 2012).

Mustard (Brassica junceae L. family Brassicaceae). This species is also known as brown mustard, Chinese mustard, Indian mustard, leaf mustard, Oriental mustard and vegetable mustard. The oil content of mustard seeds ranges from 29 to $42 \%$ in different accessions of the VIR collection. A special feature of mustard oil is the presence of eicosenic acid $\left(\mathrm{C}_{20: 1}\right)$ - up to $17 \%$ - and erucic acid $\left(\mathrm{C}_{22: 1}\right)$ - up to $40 \%$ of all unsaturated acids (Tab. 2). Behenic acid $\left(\mathrm{C}_{22: 0}\right)$ is present in a small amount (about $1 \%$ ). In spite of the presence of long-chain fatty acids, mustard oil is edible. Breeding of the crop is aimed at the reduction of the amount of erucic acid, and mutant lines without it were obtained Zm1and Zm2 (Nizova et al., 1999)

Camelina (Camelina sativa (L.) family Brassicaceae). Camelina is also known as gold-of-pleasure or false flax, also occasionally wild flax, linseed dodder, German sesame and Siberian oilseed. This crop belongs to the group of plants containing oil with linolenic and eicosenic acids dominating. The content of the main fatty acids in camelina oil in the VIR collection is: palmitic acid 5.4-6.7\%, stearic acid $2.0-2.3 \%$, oleic acid 14.0-15.7\%, linoleic acid 17.3-20.5\%, linolenic acid 33.0-40.9\%, eicosenic acid 13.9-16.1\% (Tab. 2). The ratio of fatty acids in camelina oil differs significantly from the oils of other oilseed crops of the family Brassicaceae, not only by its low amount of erucic acid (1.3-4.5\%), but also by its significant amounts of saturated fatty acids, more than $13 \%$ (Ghamkar et al., 2010). Camelina oil is characterized by a high content of polyunsaturated fatty acids (more than $70 \%$ ) and a sufficient amount of monounsaturated fatty acids, up to $35 \%$ (Nizova et al., 1999). Camelina oil is resistant to oxidation due to the presence of tocopherols, which are powerful natural antioxidants. For technical purposes, camelina oil is used as a raw material for the production of environmentally friendly biodiesel (Nagornov et al., 2014).

Eruca (Eruca sativa L. family Brassicaceae). Eruca is characterized by high (up to $55 \%$ ) erucic acid content (Tab. 2). A low (36.5\%) content of erucic acid was found in VIR accession k-338 from Pakistan. For almost all accessions evaluated in 1999 in the Leningrad region, the percentage of erucic acid was higher than for that of the Tambov region. For some accessions, for example, k-337 from the United States, the differences were statistically significant. With an increase in erucic acid content, there was a decrease in the amount of both saturated fatty acids (palmitic and stearic) and unsaturated ones-oleic and linoleic acids. The linolenic acid content was not changed, and the amount of lignoceric acid $\left(\mathrm{C}_{24: 0}\right)$ increased.

Flax (Linum usitatissimum L. family Linaceae). Linum has varieties for various purposes and is used to produce both fibre (flax) and oil (linseed). Seeds contain $40-53 \%$ oil and up to $30 \%$ protein. Flax oil contains five basic fatty acids: two saturated - palmitic (5-7\%) and stearic (3-4\%) and three unsaturated - oleic (16-20\%), linoleic (14-17\%) and linolenic (50-60\%) (Tab. 3). Linolenic acid $\left(\mathrm{C}_{18: 3}\right)$ prevails in the oil of most accessions, due to which linseed oil has unique healing and technical properties, but at the same time it contributes to rapid oil oxidation and complicates the use of the oil in the food industry (Kutuzova et al., 1998, Gavrilova et al., 2005a).

In the process of fatty acids synthesis in flax, the carbon chain elongation from $\mathrm{C}_{16}$ to $\mathrm{C}_{18}$ occurs under the influence of synthetase encoded by the FAB1 gene. The formation of double bonds occurs under the control of the desaturase enzyme system, which is encoded by the genes $S A D 1$ and $S A D 2$, and converts stearic acid into oleic acid. Each $S A D$ gene contains three exons and two introns; SAD1 length is $3626 \mathrm{bp}$, and SAD2 is $2519 \mathrm{bp}$. Both genes encode proteins of 396 amino acids with a homology of $91 \%$ for the genes sequences and $99 \%$ for the protein structure. For $S A D 1$, four isoforms are known, and the first one, A (three alleles with synonymous replacements), is present in almost all 120 accessions of the Canadian flax collection, evaluated for their fatty acid compositions (Thambugala et al., 2013).

The next stage of desaturation, which forms linoleic acid $\left(\mathrm{C}_{18: 2}\right)$, is controlled by genes FAD2A and FAD2B. 


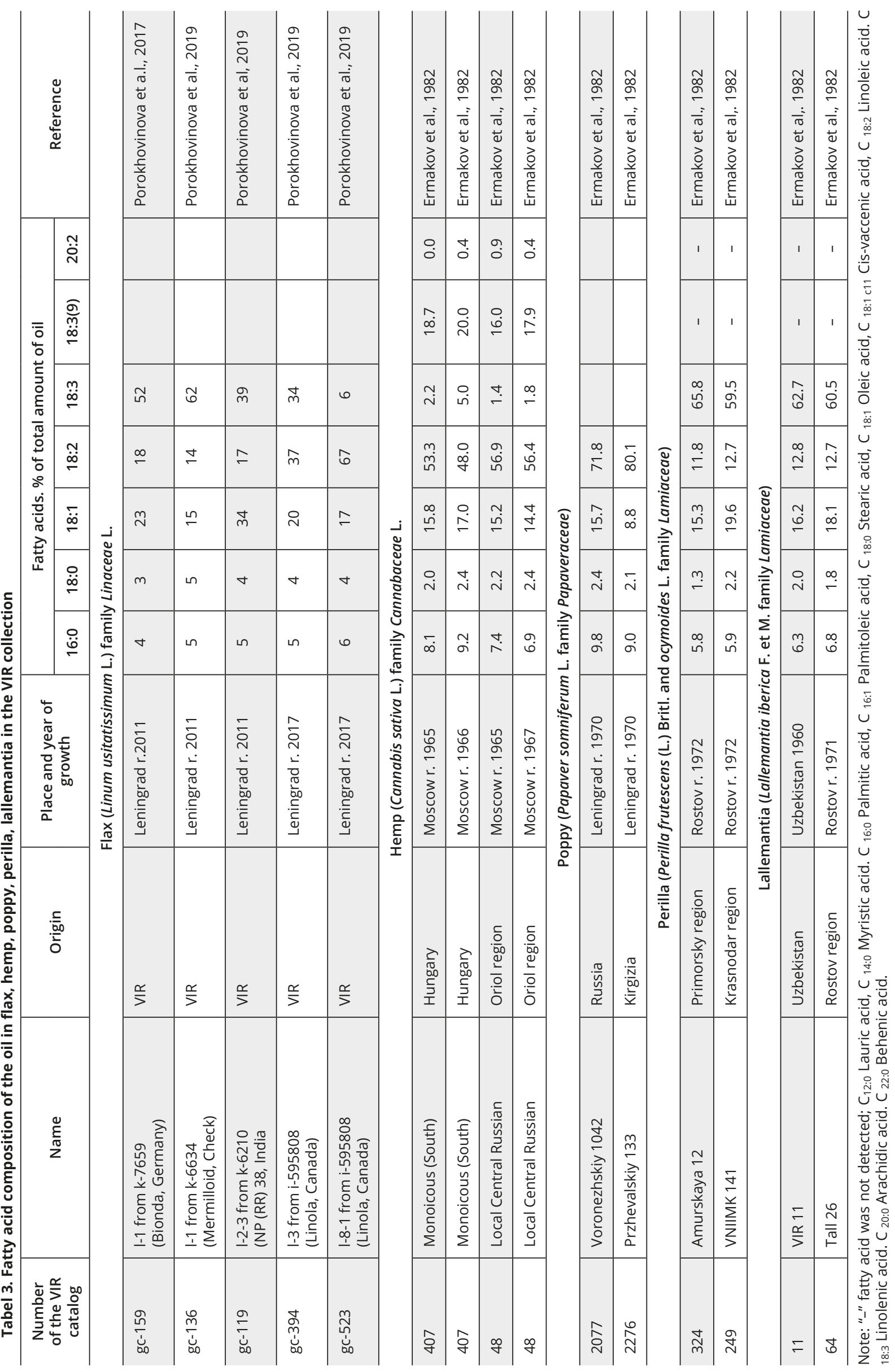


Linolenic acid $\left(\mathrm{C}_{18: 3}\right)$ is formed under the influence of genes FAD $3 A$, FAD $3 B$ and FAD $3 C$. FAD $3 A$ and FAD $3 B$ genes, having 3280 and 3002 bp respectively, contain six exons and five introns and encode proteins of 391 and 392 amino acids. The similarity of these gene sequences is $85 \%$ and similarity of the protein sequences is $94 \%$. The size of the genes differs due to indels from 1 to $29 \mathrm{bp}$, located in introns. For the FAD $3 A$ gene, six isoforms are known, four of which do not lead to inactivation of the enzyme. The first one, A (eight alleles with synonymous substitutions), is the most common; isoforms $\mathrm{B}$, $\mathrm{C}, \mathrm{E}$ (one to two alleles) are rare. Isoforms $\mathrm{D}$ and $\mathrm{E}$ have lost their functionality due to nonsense mutations. For $F A D 3 B$, seven isoforms are known. Of them, five do not lead to inactivation of the enzyme. These are isoforms A (four alleles), D (eight alleles), G (seven alleles) E and F (two alleles). Only two isoforms do not give a complete product. They are $\mathrm{B}-$ due to the nonsense mutation in the first exon and $\mathrm{C}-$ due to the replacement of histidine by tyrosine in the first His-box of the active center of desaturase. All accessions with genes forming inactive product were obtained by EMS-mutagenesis (Thambugala et al., 2013).

The first varieties with a low amount of linolenic acid content (solin) appeared only in the late 1970s in Canada (Green, 1986). They contained about $2 \%$ linolenic acid and were double recessive homozygotes of the complementary genes $\ln 1$ and $\ln 2$ (lufad $3 a$ and $\operatorname{lufad} 3 b$ ). Then other varieties were bred, as descendants of the Linola variety, or created independently of it. These varieties are widely cultivated, but patented and practically inaccessible for scientific research (Brutch et al., 2016).

Thus, two groups of varieties were formed: highlinolenic, containing in oil 30-70\% linolenic acid, and low-linolenic, having about $3 \%$ linolenic acid (Tab. 3). For a healthy diet, it is important to achieve an optimal ratio of omega-6/omega-3 fatty acids. For a normal diet this ratio should be 5-10/1, and for a therapeutic diet 3-5/1 (Rational Nutrition..., 2008). Most of the varieties have a ratio of $\sim 0.25 / 1$. Therefore, for food use, and especially for the production of full-fat flour from seeds, it is necessary to reduce the content of linolenic acid. In the low-linolenic varieties bred to date, this ratio is 13.224.6/1. Thus, neither traditional (containing too much linolenic acid) nor low-linolenic (synthesizing too little of it) flax varieties give the optimal ratio of omega- 6 and omega- 3 fatty acids. Genes $f a d 3 a$ and $f a d 3 b(\ln 1$ and $\ln 2)$ are considered valuable for flax breeding, since they encode desaturases that convert linoleic acid into linolenic acid, necessary for industrial oil, but undesirable for food (You et al., 2014).

Now varieties with a medium content of linolenic acid are gaining popularity. Their oil can be stored longer than oil with a high amount of linolenic acid, but it is more useful than oil with a low amount. One of the first varieties of that kind was Raciol (Czech Republic, AGRITEK), which has approximately the same amount of linoleic and linolenic acids (Tejklova et al., 2011). A line with a decreased content of linoleic and linolenic acids in the oil due to an increase of oleic acid was created in VIR (Prokhovinova et al., 2019) (see Tab. 3).

Hemp (Cannabis sativa L. family Cannabaceae Lindl.) Hemp is characterized by a balanced content of linoleic (about 50\%) and linolenic (about 20\%) acids (Tab. 3). Due to this, hemp oil is not oxidized as quickly as linseed oil. Linolenic acid is represented by both omega-6 (0.2-5.0\%) and omega-9 (14.4-20.2\%) forms. In addition to that, hemp oil contains a small amount of eicosadiene $\left(\mathrm{C}_{20: 2}\right)$ acid. This fatty acid composition is extremely useful for nutrition.

The nutritional value of hemp oil is determined not only by its fatty acids composition, but also by the ratio between separate components or their groups between themselves (Grigoriev and Illarionova, 2015). The ratio of monounsaturated and saturated fatty acids in hemp oil is approximately $2 / 1$. The presence of tetraunsaturated cis-6,9,12,15 octadecatetraenoic omega-3 fatty acid makes hemp oil unique. The content of alpha-linolenic and, to a greater extent, gamma-linolenic acids in oil varies depending on the geographical location of hemp cultivation: the minimum content of these substances was found in seeds produced in the Southern Federal District of the Russian Federation, and the maximum content - in seeds from the Siberian Federal District. Changes in the content of polyunsaturated fatty acids of hemp seed oil can be traced from the Southwest to the East of Russia (Shelenga et al., 2011).

Poppy (Papaver somniferum L. family Papaveraceae Juss.). The poppy is a very polymorphic species. The oilseed poppy is a subspecies, Eurasiaticum (Veselovskaya, 1975). European forms of poppy are low in morphine and are cultivated for food purposes. Oil poppies are mainly cross-pollinated, so this subspecies is very diverse in morphological characters - the color of flowers, seeds and the shape of capsules. Poppy oil has excellent taste, and the absence of linolenic acid in its composition allows the oil to be stored for a long time. The oil is obtained by pressing or extraction. Cold pressing gives approximately $30-35 \%$ of the light-yellow oil, which is used for food purposes. After hot pressing (at $115^{\circ} \mathrm{C}$ ), the oil is dark yellow or reddish and is used only as a refined product (Salunkhe and Desai, 1986). For food, not only is poppy oil used, but also the whole seeds, as a supplement to bakery products.

Poppy accessions with dark seeds have $37-50 \%$ oil, including breeding varieties with $44-50 \%$; forms with light seeds have more oil, $43-56 \%$. The oil content in the seeds also depends on the growing conditions. Increased doses of nitrogen fertilizers lead to an increase in seed yield and protein content, and oppositely affect oil con- 
tent (Kutuzova et al., 1998). Poppy seed oil contains $65 \%$ linoleic acid, $25 \%$ oleic acid and 6-10\% saturated fatty acids. Table 3 shows the fatty acid composition of oil in poppy varieties with contrasting levels of oleic and linoleic fatty acids (Ermakov et al., 1982).

Breeding of oilseed poppies in the USSR began in the 1930s, but as it was a crop of bilateral use (food and medicinal), special attention was paid to the increase of the morphine content in dry capsules. Due to the increase of drug addiction in the 1980s, the direction of breeding was changed to the creation of poppy varieties exclusively for food use. Currently in Russia two opiumfree low-alkaloid varieties of poppy for oilseeds and confectionery use have been released.

Perilla (Perilla frutescens (L.) Britt.) and lallemantia (Lallemantia iberica Fisch et Mey) family Lamiáceae. In the oil of minor crops perilla and lallemantia, as in flax oil, linolenic acid (60.5\%-62.7\%, Tab. 3$)$ is dominating. Unfortunately, the properties of these oils have not been evaluated sufficiently. On the territory of the Russian Federation, perilla is a prospective crop in the Far East, while in other areas it is impossible to obtain a seed yield. Seeds retain germination ability for only one year. Lallemantia is capable of producing seeds in the southern regions of the Russian Federation.

Castor bean (Ricinus communis L. family Euphorbiaceae). Castor bean seeds contain up to $70 \%$ oil. This oil thickens in the air, but is not covered by film and is not oxidized. (Moshkin, 1980). The oil is dense, viscous (18 times more viscous than sunflower oil) and non-drying, with a low pour point $\left(-18^{\circ}\right.$ to $\left.-22^{\circ} \mathrm{C}\right)$. Castor oil dissolves in alcohol and by this feature differs from other vegetable oils, but it does not dissolve in mineral oil and gasoline, does not affect rubber and does not leave any residue when burned. The oil contains palmitic acid (0.9-1.5\%), stearic acid (1.4-2.1\%), linoleic acid (2.5-6.5\%), oleic acid (3.1-5.9\%), ricinolenic acid or ricinoleic acid $\left(\mathrm{C}_{18} \mathrm{H}_{34} \mathrm{O}_{3}\right)$ (Tab. 4). Ricinoleic acid (12-OH-delta 9-18:1) has one unsaturated bond, a high molecular weight and a low melting point $\left(5^{\circ} \mathrm{C}\right)$. Ricinoleic acid is synthesized on the basis of the oleic acid under the unusual action of the gene $\mathrm{fad} 2$, and makes up $85-95 \%$ of castor oil (Ohlrogge and Browse, 1995). These properties of castor oil make it an indispensable lubricant for engines operating in severe conditions, namely in rocket engines and rocket technology, in the Far North, in precision instruments and watches and in hydraulic brake fluid. Castor oil is used for the production of high quality varnishes and paints, plastics, artificial fibres, printing inks, rubber, insulation materials, toilet soap, textile (for impregnation and etching of fabrics) and in the leather industry (for greasing leather), not to mention its use in perfumery (for aromatics and lipstick) and medicine, where castor oil (or ricin oil) is used as a bactericidal agent and a strong laxative, as well as in the manufacture of various ointments. In India, it is used for lighting, as it gives white non-smoking flame (Moshkin, 1980).

Castor bean plants contain the alkaloid ricinin $\left(\mathrm{C}_{8} \mathrm{H}_{8} \mathrm{O}_{2} \mathrm{~N}_{2}\right)$, the monocyclic pyrimidine derivative with a cyanide group. The initial substance for its biosynthesis is nicotinic acid. For humans, ricinin is of low toxicity, but moth caterpillars die from it. Accumulation of ricinin occurs in the vegetative organs, and then in generative parts. The seeds accumulate the poisonous protein ricin, which belongs to the phytotoxins, the most poisonous proteins. The degree of its toxicity is comparable to that of the tetanus, botulism and diphtheria toxins. Both ricinin and ricin do not get into the oil and remain in oilcake or meal, so castor oil is not toxic.

Sesame (Sesamum indicum L. family Pedaliaceae). Sesame is an oil crop grown all over the world. Sesame is one of the few oilseeds for food purposes with the highest content and quality of oil. Sesame seeds contain $50-64 \%$ oil, up to $27 \%$ protein and $20 \%$ carbohydrates. Among the 369 Sesamum species, the oil content ranges from $27.89 \%$ to $58.73 \%$, and the protein content ranges from $16.72 \%$ to $27.79 \%$ (Li et al., 2014). Sesame oil is stable due to the presence of natural antioxidants such as sesamolin, sesamin and sesamol (Anilakumar et al., 2010). Sesame oil contains $46-49 \%$ oleic acid, 38-41\% linoleic acid, 8-9\% palmitic acid, 4-5\% stearic acid and $0.4-1 \%$ arachidonic acid. The ratio of the two main fatty acids (oleic and linoleic) is almost ideal, 1/1 (Tab. 4) (Bedigian and Harlan, 1986; Anilakumar et al., 2010). Sesame oil produced by cold pressing seeds is a food product with high taste qualities. By hot pressing, oil for technical purposes is obtained, for example, for the production of mascara. From white sesame seeds, tahini oil is obtained, which is used in the production of various sweets.

Peanut (Arachis hypogaea L.family Fabaceae). Peanut oil forms $44-56 \%$ of dry seed weight and consists of various fatty acids. Essential fatty acids include oleic $\left(\mathrm{C}_{18: 1}\right)$, linoleic $\left(\mathrm{C}_{18: 2}\right)$, palmitic $\left(\mathrm{C}_{16: 0}\right)$, stearic $\left(\mathrm{C}_{18: 0}\right)$, arachidic $\left(\mathrm{C}_{20: 0}\right)$, behenic $\left(\mathrm{C}_{22: 0}\right)$, lignoceric $\left(\mathrm{C}_{24: 0}\right)$ and gadoleic $\left(\mathrm{C}_{20: 1}\right)$ acids (Chen et al., 2010). Peanut oil contains about $80 \%$ unsaturated fatty acids and $20 \%$ saturated fatty acids. Unsaturated fatty acids are presented by $42 \%$ oleic and $37 \%$ linoleic acid (Tab. 4) (Wang et al., 2015). Tests of 10 peanut accessions from our collection revealed 15 fatty acids. Contents of some of them did not exceed $1 \%$, including palmitoleic or hexadec9-enoic acid $\left(\mathrm{C}_{16: 1}\right)$. Hypogaeic (hexadec-7-enoic) acid is a specific compound of peanut oil which was found in the middle of the previous century (Hoerr and Osol, 1956). This acid is also found in human breastmilk, and can be important for the production of baby food. But unfortunately, now scientists do not pay attention to this substance in peanut oil. 


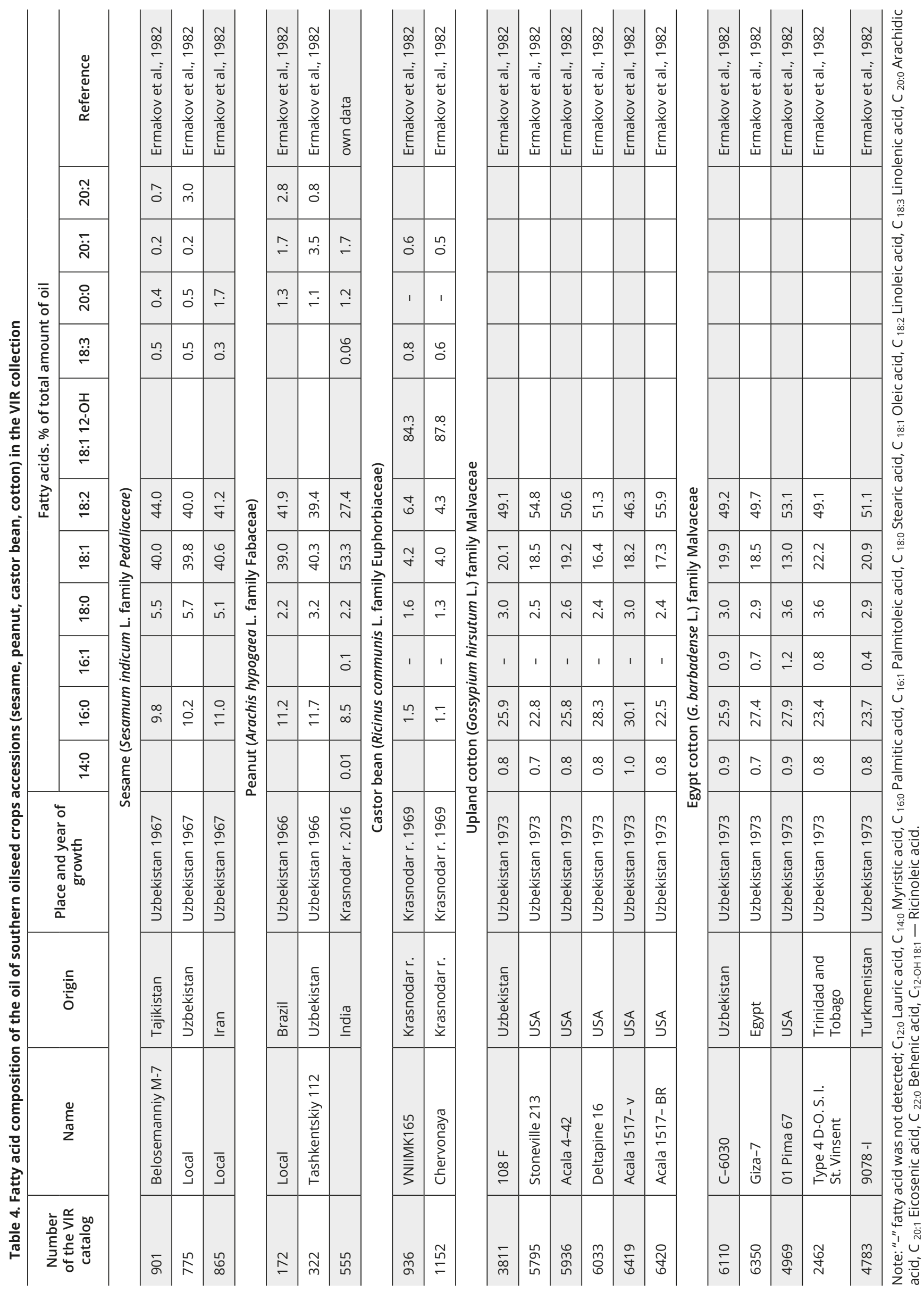


Peanut oil with a maximum content of linoleic acid is vulnerable to oxidation, which leads to an unpleasant smell, taste and short expiration of oil and other peanut products. The third major fatty acid is palmitic $\left(\mathrm{C}_{16: 0}\right)$ acid, which is about $10 \%$ of the total oil content. The remaining $10 \%$ are minor fatty acids (Wang et al., 2015). In general, human consumption of peanut oil with a high content of oleic acid and a low content of linoleic acid is preferable, because it reduces the risk of cardiovascular diseases by reducing the level of low-density lipoproteins in the blood (Vassiliou et al., 2009). In this regard, the identification of the first peanut mutants with a high level of oleic $(80 \%)$ and low level of linoleic (2\%) acids - F435-2-1 and F435-2-2 - was a breakthrough in improvement for peanut oil quality (Norden et al., 1987).

The content of oleic acid in peanuts is controlled by two recessive genes, $o l_{1}$ and $o l_{2}$ (Moore and Knauft, 1989). Modifier genes involved in the synthesis of oleic acid at medium and low levels were later found (Lopez et al., 2001). Mercier et al. (1990) discovered that additive effects are more important than non-additive effects in the inheritance of oleic and linoleic acids levels and their ratios. Intermediate and high estimates of these characters' heritability showed the possibility of their improvement in the original peanut population (Singkham et al., 2010). The stage of seed maturity also affects oleic acid content (Golombek et al., 1995; Hinds, 1995).

The ratio between oleic and linoleic acids in most commercial peanut varieties varies ranges from $1 / 1$ to 2.5/1 (Lopez et al., 2000), while the mutant F435 has a ratio of about 35/1 (Norden et al., 1987). This high-oleic phenotype had two recessive mutations ahFAD2A and ahFAD2B (Moore et al., 1989; Jung et al., 2000). In 20102016 in India, crosses were made between peanut accessions with low, medium and high levels of oleic acid. The results confirmed that the enzyme that catalyzes the desaturation of oleic to linoleic acid is encoded by the genes FAD2A and FAD2B (Gangadhara and Nadaf, 2016). Also, it was found that this enzyme is encoded by two homologous genes (ahFAD2A and ahFAD2B) located in A and B subgenomes, respectively. Both FAD genes have $99 \%$ sequence homology and inactivation of corresponding enzyme results in high oleic acid content in mutants due to replacement (G: C by A: T) and insertion (A: T) of one base pair in FAD genes located in subgenomes A and B, respectively (Chen et al., 2010). These mutations lead to the accumulation of more oleic acid and the reduction of linoleic and palmitic acids, which improves oil quality by increasing storage life. Molecular mapping of peanut oil content and fatty acid composition was recently performed (Shasidhar et al., 2017).

Cotton (Gossypium L. family Malvaceae). Cotton is a major world fibre crop. It is cultivated to a differ- ent extent in 89 countries in the tropical and subtropical zones. The main producers of this crop are India, the USA, China, Pakistan and Uzbekistan (FAOSTAT, 2019). Cotton fibre is the outgrowths of the seed exotestal-unicellular trichomes. Fibre makes up 30-40\% of the seed weight; $2 / 3$ of the raw cotton yield falls on the actual seeds, which also find different applications, primarily as a source of vegetable oil for food and technical purposes.

Cottonseed oil contains $40-55 \%$ linoleic acid, $18-30 \%$ oleic acid, $20-25 \%$ palmitic acid, up to $1.2 \%$ palmitoleic acid, 2-7\% stearic acid and a small amount of myristic and arachidonic acids. A distinctive feature of the Malvaceae family is the presence of cyclopropane acids in the oil. Cottonseed oil contains from 0.5 to $2 \%$ malvalic, sterculic and dihydrosterculic acids. The content of tocopherols is $0.92 \mathrm{mg} / \mathrm{g}$, including $55.4 \%$ alpha and $44.6 \%$ gamma (Dowd, 2015). A distinctive feature of all cotton types is the presence of small glands in the plant organs containing fat-soluble gossypol. Gossypol is a polyphenolic terpenoid that has a significant influence on how the seed is processed and used. Gossypol in cottonseed is of particular importance, as the compound responsible for anti-nutritive and toxicity issues associated with the overfeeding of cottonseed products. This pigment makes up 1-2\% of cotton seeds, so oil intended for food purposes must be refined and deodorized. Oil is produced by pressing and extraction. It is used to produce salad oil and frying oil, margarine, mayonnaise and lard substitute.

In the 1970s the fatty acids composition of some accessions of the VIR cotton collection was evaluated. We present here data on accessions grown in 1973 (Tab. 4). Already from this small example it can be seen that the collection presents all kinds of cotton fatty acids composition. Interestingly, the species Gossypium barbadense L. differs from G. hirsutum L. by the presence in its oil of palmitoleic acid, which reaches $1.2 \%$. The absence of references on this acid in the bibliography is probably based on the fact that analyses were made mainly of medium-fibre cotton, the most common and in demand.

Active work is currently underway on identification of the genes responsible for the synthesis of fatty acids, as well as attempts to transform them in order to reduce the content of saturated palmitic acid and increase the content of linoleic acid (Liu et al., 2002). American scientists in 2001 reported the creation of transgenic cotton plants with high oleic acid content in seeds (Liu et al., 2002). These plants were obtained by transformation mediated by Agrobacterium for suppressing the expression of the cotton $\mathrm{fad} 2$ gene and introducing the mutant allele of the soybean $\mathrm{fad} 2$ gene into the cotton genotype. The increase of oleic acid content to $47 \%$ was achieved due to the decrease of linoleic acid. 


\section{Conclusion}

Different oil crops are characterized by their own fatty acids composition. At the same time, among the different accessions of each crop there is a hereditary diversity of each fatty acid content. A significant change in the fatty acids composition leads to changes in oil utilization. Representatives of the oil crops of the Asteraceae family have a similar fatty acids composition with a predominance of oleic or linoleic acids and the absence of long-chain fatty acids with 20,22 and 24 carbon atoms. Linolenic acid in the oil of these crops is practically absent. Oil becomes inedible either due to the high content of long-chain fatty acids, as it is in representatives of the Brassicaceae family, or because of the presence of toxic compounds like in castor oil. All crops presented in the article can be cultivated on the territory of the Russian Federation. Currently, the area of industrial crops are known for sunflower (6-7 million hectares annually), rapeseed (about 700 thousand-1 million hectares), flax (700 thousand hectares), mustard (up to 150 thousand hectares), camelina (140 thousand hectares) and safflower (up to 400 thousand hectares). Industrial cultivation of hemp, which is now permitted and is developing, now exceeds 3.5 thousand hectares. The castor bean is a prospective and strategically important industrial crop. Cotton, noog, peanuts, sesame and lallemantia are promising for future cultivation.

\section{Acknowledgements}

The work was carried out in the framework of state assignment № AAAA-A19-119013090159-5 to VIR, project No. 04812019-0001.

\section{References}

Anilakumar, K., Pal, A., Khanum, F., and Bawas, A. 2010. Nutritional, medicinal and industrial uses of sesame (Sesamum indicum L.) seeds. Agriculturae Conspectus Scientificus 75(4):159-168.

Bedigian, D. and Harlan, J. 1986. Evidence for cultivation of sesame in the ancient world. Economic Botany 40:137154. https://doi.org/10.1007/BF02859136

Bocianowski, J., Mikołajczyk, K., and Bartkowiak-Broda, I., 2012. Determination of fatty acid composition in seed oil of rapeseed (Brassica napus L.) by mutated alleles of the FAD3 desaturase genes. Journal of Applied Genetics 53(1):27-30. https://doi.org/10.1007/s13353-011-0062-0

Brar, G. and Thies, W. 1978. Biosynthesis of $a$-linolenic acid in leaves and seeds of rape (Brassica napus L.). Proceedings of the $5^{\text {th }}$ International Rapeseed Conference 2:27-30.

Brutch N. B., Porokhovinova E. A., and Shelenga T. V. 2016. Innovative possibilities of oil flax breeding orientated at the different oil composition. Dostizheniya nauki i tekhniki APK 30(6):5-8. (In Russian)

Burkhardt, H. 1971. Phosphatides isolation from seeds of com-mercial and experimental safflower varieties. Journal of American Oil Chemists Society 48(11):607-699. https://doi.org/10.1007/BF02638523

Cao, S., Zhou, X., Wood, C., Green, A., Singh, S., Liu, L., and Liu, Q. 2013. A large and functionally diverse family of
Fad2 genes in safflower (Carthamus tinctorius L.). BMC Plant Biology 13:5. https://doi.org/10.1186/1471-222913-5

Chen, Z., Wang, M., Barkley, N., and Pittman, R. 2010. A simple allele-specific PCR assay for detecting FAD2 alleles in both $A$ and $B$ genomes of the cultivated peanut for high-oleate trait selection. Plant Molecular Biology Reporter 28:542-548. https://doi.org/10.1007/s11105010-0181-5

Chernova, A., Mazin P., Goryunova, S., Goryunov, D., Demurin, Ya., Gorlova, L., Vanyushkina, A., Mair, W., Anikanov, N., Yushina,E., Pavlova, A., Martynova, E., Garkusha, S., Mukhina, Zh., Savenko, E., and Khaitovich, Ph. 2019. Ultra-performance liquid chromatography-mass spectrometry for precise fatty acid profiling of oilseed crops. Peer] 7:e6547 https://doi.org/10.7717/peerj.6547

Demurin, Y. and Borisenko, O. 2011. Genetic collection of oleic acid content in sunflower seed oil. Helia 34:69-74. https://doi.org/10.2298/HEL1155069D

Demurin, Ya., Borisenko, O., Chebanova, Yu., and Levutskaya, A. 2016. Maternal effect in inheritance of mid-oleic acid content in the $F_{1}$ seeds of sunflower. Maslichnye kultury 1(165):16-21. (In Russian)

Dergisi, O. 2007. Seed yield, oil content and fatty acids composition of safflower (Carthamus tinctorius L.) grown in northern Turkey conditions. Journal of Agricultural Faculty OMU 22(1):98-104.

Dowd, M. 2015. Seed: in Cotton, agronomy monograph 57. Second addition. American Society of Agronomy, Inc., Crop Science Society of America, Inc., and Soil Science Society of America, Inc. pp. 745-782. https://doi. org/10.2134/agronmonogr57.2013.0032

Ermakov, A., Davidyan, G., Yarosh, N., Anashchenko, A., Lemeshev, N., Rykova, R., and Megorskaya, O. 1982. Oil crops (Characters of oil quality according to fatty acids content). Leningrad, VIR. (In Russian)

FAOSTAT. 2019. http://www.fao.org/faostat/en/\#data

Fernandez-Martinez, J. M., Jimenez, A., and Dominguez, J. 1989. Genetic analysis of the high oleic acid content in cultivated sunflower (Helianthus annuus L.). Euphytica 41:39-51. https://doi.org/10.1007/BF00022409

Fernandez-Martinez, J., Perez-Vich, B., Velasco, L., and Dominguez, J. 2007. Breeding for speciality oil types in sunflower. Helia 30(46):75-84. https://doi.org/10.2298/ HEL0746075F

Fernandez-Martinez, J., Velasco, L., and Perez-Vich, B. 2004. Progress in the genetic modification of sunflower oil quality. Proceedings of 16th International sunflower conference 1:1-14.

Futehally, S. 1982. Inheritance of very high levels of linoleic acid in the seed oil of safflower (Carthamus tinctorius L.). MS Thesis, University California, Davis CA USA.

Gangadhara, K. and Nadaf, H. 2016. Inheritance of oleic acid content in new sources of groundnut (Arachis hypogaea L.). Agricultural Science Digest 36(4):299-302. https:// doi.org/10.18805/asd.v36i4.6472

Gavrilova, V., Dubovskaya, A., Kon'kova, N., Brutch, N., and Porokhovinova, E. 2005. Genetic and breeding aspects determining quality of seeds, oil and oilcake of flax, sunflower, rapeseed and camelina, pp. 20-22 in Materials of 5 International conference "Oil-fat industry - 2005: facts, determining oil-fat products quality" Sankt-Peterburg. (In Russian)

Gavrilova, V., Dubovskaya, A., Konkova, N., and Nizova, G. 2005. Perspectives and reality of using vegetable oils as biofuel. Maslozhirovaya promyshlennost 8:15-17.

Ghamkar, K., Croser, Ja., Aryamanesh, N., Campbell, M., Kon'kova, N., and Francis, C. 2010. Camelina (Camelina 
sativa (L.) Crants) as an alternative oilseed: molecular and ecogeographic analyses. Genome 53(7):558-567. https://doi.org/10.1139/G10-034

Golombek, S., Sridhar, R., and Singh, U. 1995. Effect of soil temperature on seed composition of three Spanish cultivars of groundnut (Arachis hypogaea L.) Journal of Agricultural and Food Chemistry 43:2067-2070. https://doi. org/10.1021/jf00056a021

Gorlov, S., Bochkaryova, E., Gorlova, L., and Serdyuk, V. 2015. High oleic rapeseed variety Amulet. Maslichnye kultury. Nauchno-tekhnichesky byulleten Vserossyskogo nauchnoissledovatelskogo instituta maslichnykh kultur 2(162):127128.

Green, A. 1986. Genetic control of polyunsaturated fatty acid biosynthesis in flax (Linum usitatissimum) seed oil. Theoretical and Applied Genetics 72(5):654-661. https://doi. org/10.1007/BF00289004

Grigoryev, S. and Illarionova, K. 2015. Results of breeding of industrial hemp textile, oilseeds and medicinal areas of use in the Russian Federation. Trudy Kubanskogo gosudarstvennogo agrarnogo universiteta 55:44-48. (In Russian)

Hinds, M. 1995. Fatty acid composition of Caribbean-grown peanuts (Arachis hypogaea L.) at three maturity stages. Food Chemistry 53:7-14. https://doi.org/10.1016/03088146(95)95779-6

Hoerr, N. L. and Osol, M. D. A. (ed). 1956. New gold medical dictionary (2nd ed.). London. 821.

Ivanov, P., Petakov, D., Nikolova, V., and Pentchev, E. 1988. Sunflower breeding for high palmitic acid content in the oil. Proceedings 12th International sunflower conference 2:463-465.

Jung, S., Powell, G., Moore, K., and Abbott, A. 2000. The high oleate trait in the cultivated peanut (Arachis hypogaea L.) II Molecular basis and genetics of the trait. Molecular Genetics and Genomics 263:806-811. https://doi. org/10.1007/s004380000243

Knowles, P. 1989. Safflower. pp. 363-374 in Robbelen, G., Downey, R. K., and Ashri A. (eds), Oil Crops of the Wold.

Knowles, P. and Hill, A. 1964. Inheritance of fatty acid content in the seed oil of a safflower introduction from Iran. Crop Science 4:406-409. https://doi.org/10.2135/cropsci1964. $0011183 \times 000400040023 x$

Knowles, P., Hill, A., and Ruckman, F. 1965. High oleic acid content in new safflower, UC-1. California Agriculture 19:12-15. https://doi.org/10.1007/BF02971186

Krasilnikova, L., Avksentyeva, O., Zhmurko, V., and Sadovnichenko, Yu. 2004. Plants biochemistry. 224 pp. Rostov-on-Don: Feniks, Kharkov: Torgsing. (In Russian)

Krzymanski, J. and Downey, R. 1969. Inheritance of fatty acid composition in winter forms of rapeseed, B. napus. Canadian Journal of Plant Science 49(3):313-319. https://doi. org/10.4141/cjps69-053

Kutuzova, S., Gavrilova, V., Shchelko, L., Dubovskaya, A., Kartamysheva, Ye., Vakhrusheva, T., Brutch, N., Grigor'yev, S., Matveyeva, G., and Podol'naya, L. 1998. Oil crops for nutrition purposes (breeding problems, sortiment). Saint Petersburg, VIR. (In Russian)

Ladd, S. and Knowles, P. 1971. Interactions of alleles at two loci regulating fatty acid composition of the seed oil of safflower (Carthamus tinctorius L.). Crop Science 11:681684. https://doi.org/10.2135/cropsci1971.0011183X001 $100050024 x$

Ladd, S. and Knowles, P. 1970. Inheritance of stearic acid in the seed oil of safflower (Carthamus tinctorius L.). Crop Science 10:525-27. https://doi.org/10.2135/cropsci1970. 0011183X001000050022x
Li, C., Miao, H., Wei, L., Zhang, T., Han, X., and Zhang, H. 2014. Association mapping of seed oil and protein content in Sesamum indicum L. using SSR markers. PLOS ONE. 9(8):e105757. https://doi.org/10.1371/journal. pone. 0105757

Liu, L., Guan, L., Wu, W., and Wang, L. 2016. A review of fatty acids and genetic characterization of safflower (Carthamus tinctorius L.) seed oil. Current Organic Chemistry 5(1): 1000160. https://doi.org/10.4172/2161-0401.1000160

Liu, Q., Singh, S., and Green, A. 2002. High-stearic and higholeic cottonseed oils produced by hairpin RNA-mediated post-transcriptional gene silencing. Plant Physiology 129:1732-1743. https://doi.org/10.1104/pp.001933

Lopez,Y., Nadaf, H., Smith, O., Connel, J., Reddy, A., and Fritz, A. 2000. Isolation and characterization of the Delta(12)-fatty acid desaturase in peanut (Arachis hypogaea L.) and search for polymorphisms for the high oleate trait in Spanish market-type lines Theoretical and Applied Genetics 101:1131-1138. https://doi.org/10.1007/ s001220051589

Lopez, Y., Smith, O., Senseman, S., and Rooney, W. 2001. Genetic factors influencing high oleic acid content in Spanish market-type peanut cultivars. Crop Science 41:51-56. https://doi.org/10.2135/cropsci2001.41151x

Mercer, L., Wynne, J., and Young, C. 1990. Inheritance of fatty acid content in peanut oil. Peanut Science 17:17-21. https://doi.org/10.3146/i0095-3679-17-1-7

Miller, J., Zimmerman, D., and Vick, B. 1987. Genetic control of high oleic acid content in sunflower oil. Crop Science 27:923-926. https://doi.org/10.2135/cropsci1987.00111 83X002700050019x

Minkevich, I. 1939. Safflower. Krasnodar: Krayevoye knizhnoe izdatelstvo. pp. 10-12. (In Russian)

Moore, K. and Knauft, D. 1989. The inheritance of high oleic acid in peanut. Journal of Heredity 80(3):252-253. https:// doi.org/10.1093/oxfordjournals.jhered.a110845

Moshkin, V. 1980. Castor bean. 352 p. Trudy VASKHNIL. (In Russian)

Nagornov, S., Romantsova, S., Gavrilova, V., and Konkova, N. 2014. Use of camelina oil for biodiesel production. Nauka $v$ tsentralnoy Rossii 4:34-40. (In Russian)

Nath, K., Kim, H., Khatum, K., Park, J., Kang, K., and Nou, I. 2016. Modification of fatty acid profiles of rapeseed (Brassica napus L.) oil for using as food, industrial feedstock and biodiesel. Plant Breeding and Biotechnology 4:123-134. https://doi.org/10.9787/PBB.2016.4.2.123

Nizova, G., Dubovskaya, A., Konkova, N., Librikht, A., and Gorkovenko, T. 1999. Catalog of the VIR world collection. Issue 700. Cruciferous crops. Rapeseed, bitter cress, mastard, camelina (Characteristics of the accessions for content of oil, fatty acids and protein). 57 p. Saint Petersburg, VIR. (In Russian)

Nizova, G., and Konkova, N. 2008. Catalog of the VIR world collection. Issue 783. Minor oilseeds eruca, conringia, crambe, cuphea, lallemantia, madia, euphorbia, sunflecks, perilla, safflower, oil radish, camelina, chufa (characterization of biochemical characteristics). $54 \mathrm{p}$. Saint Petersburg, VIR. (In Russian)

Norden, A., Gorbet, D., Knauft, D., and Young, C. 1987. Variability in oil quality among peanut genotypes in the Florida breeding program. Peanut Science 14:7-11. https:// doi.org/10.3146/i0095-3679-14-1-3

Ohlrogge, J. and Browse, J. 1995. Lipid biosynthesis. The Plant Cell 7:957-970. https://doi.org/10.1105/tpc.7.7.957

Perez-Vich, B., Fernandez, J., Garces, R., and Fernandez-Martinez, J. 2002. Inheritance of high palmitic acid content in the sunflower mutant CAS-12 and its relationship with 
high oleic content. Plant Breeding 121:49-56. https://doi. org/10.2298/HEL0848055V

Perez-Vich, B., Velasco, L., Munoz-Ruz, J., and Fernandez-Martinez, J. 2006. Inheritance of high stearic acid content in the sunflower mutant CAS-14. Crop Science 46:22-29. https://doi.org/10.2135/cropsci2004.0723

Porokhovinova, E. A., Shelenga, T. V., Kosykh, L. A., Sanin, A. A., Kazarina, A. V., Kutuzova, S. N., Pavlov, A. V., and Brach, N.B. 2017. Biochemical diversity of fatty acid composition in flax from VIR's genetic collection and effect of environment on its development. Russian Journal of Genetics: Applied Research 7(6):626-639. https://doi. org/10.1134/S2079059717060107

Porokhovinova, E., Shelenga, T., Matveeva, T., Pavlov, A., Grigorieva, E., and Brutch, N. 2019. Polymorphism of genes controlling low level of linolenic acid in lines from VIR flax genetic collection. Ecologitcheskaya genetica 17(2):519. https://doi.org/10.17816/ecogen1725-19

Rational nutrition, norms of physiological needs in energy and nutrients for different groups of the population in Russian Federation. Methodical recommendations MR 2.3.1.2432-08. 2008. Tutelyan, V. (add). 39 p. (In Russian)

Sakhno, L. 2010. Variability of fatty acids composition of rapeseed oil: classical breeding and biotechnology. Tsitologiya i genetika 44(6):70-80. https://doi.org/10.3103/ S0095452710060101 (In Russian)

Salunkhe, D. K. and Desai, B. B. 1986. Postharvest biotechnology of oilseeds. CRC Press. Boca Raton. Florida. 213 p.

Schmid, K. M. 2016. Chapter 4. Lipid metabolism, pp. 113-147 in Plants biochemistry of lipids, lipoproteins and membranes. (Sixth Edition) Elsevier. https://doi.org/10.1016/ B978-0-444-63438-2.00004-3

Schuppert, G., Tang, S., Slabaugh, M., and Knapp, S. 2006. The sunflower high-oleic mutant $\mathrm{Ol}$ carries variable tandem repeats of fad2-1, a seed-specific oleoyl-phosphatidyl choline desaturase. Molecular Breeding 17:241-256. https://doi.org/10.1007/s11032-005-5680-y

Shasidhar, Y., Vishwakarma, M., Pandey, M., Janila, P., Variath, M., Manohar, S., Nigam, S., Guo, B., and Varshney, R. 2017. Molecular mapping of oil content and fatty acids using dense genetic maps in groundnut (Arachis hypogaea L.) Frontiers in Plant Science 8:794. https://doi. org/10.3389/fpls.2017.00794

Shelenga, T., Grigoryev, S., Baturin, V., and Sarana, Yu. 2011. Biochemical characters of hemp seeds (Cannabis sati$v a$ L.) from different regions of Russia. Agrarnaya Rossiya 2:6-9. (In Russian)

Singkham, N., Jogloy, S., Kesmala, T., Swatsitang, P., Jaisil, P., Puppala, N., and Patanothai, A. 2010. Estimation of heritability by parent-offspring regression for high-oleic acid in peanut. Asian Journal of Plant Science 9(6):358-363. https://doi.org/10.3923/ajps.2010.358.363

Soldatov, K., Voskoboynik, L., and Kharchenko, L. 1976. High oleic acid sunflower variety Pervenets. Byulleten NTI po maslichnym kulturam 3:3-7. (In Russian)

Stefansson, B., Hougen, F., and Downey, R. 1961. Note on the isolation of rape plants with seed oil free from erucic acid. Canadian Journal of Plant Science 41(1):218. https:// doi.org/10.4141/cjps61-028

Tejklova, E., Bjelkova, M., and Pavelek, M. 2011. Medum-linolenic linseed (Linum usitatissimum L.). Czech Jornal of Genetics and Plant Breeding 47(3):128-130. https://doi. org/10.17221/96/2011-CJGPB

Thambugala, D., Duguid, S., Loewen, E., Rowland, G., Booker, H., You, F., and Cloutier, S. 2013. Genetic variation of six desaturase genes in flax and their impact on fatty acid composition. Theoretical and Applied Genetics 126:26272641. https://doi.org/10.1007/s00122-013-2161-2

Vassiliou, E., Gonzalez, A., Garcia, C., Tadros, J., Chakraborty, G., and Toney, J. 2009. Oleic acid and peanut oil high in oleic acid reverse the inhibitory effect of insulin production of the inflammatory cytokine TNF-a both in vitro and in vivo system. Lipids Health Disease 8:25. https://doi. org/10.1186/1476-511X-8-25

Velasco, L., Perez-Vich, B., and Fernandez-Martinez, J. 2000. Inheritance of oleic acid content under controlled environment. In Proceedings of 15th International Sunflower Conference. Toullouse, France. 1:A31-A36.

Veselovskaya, M. A. 1975. Poppy (diversity, classification, evolution). Sbornik nauchnich trudov po prikladnoy botanike, genetike i selektcii 55(1):175-223. (In Russian)

Wang, M., Khera, P., Pandey, M., Wang, H., Qiao, L., Feng, S., Tonnis, B., Barkley N., Pinnow, D., Holbrook, C., Culbreath, A., Varshney, R., and Guo, B. 2015. Genetic mapping of QTLs controlling fatty acids provided insights into the genetic control of fatty acid synthesis pathway in peanut (Arachis hypogaea L.). PLoS ONE 10:e0119454. https://doi.org/10.1371/journal.pone.0119454

Wei, X., Liu, K., Zhang, Y., Feng, Q., Wang, L., Zhao, Y., Li, D., Zhao, Q., Zhu, X., Zhu, X., Li, W., Fan, D., Gao, Y., Lu, Y., Zhang, X., Tang, X., Zhou, C., Zhu, Ch., Liu, L., Zhong, R., Tian, Q., Wen, Z., Weng, Q., Han, B., Huang, X., and Zhang, X. 2015. Genetic discovery for oil production and quality in sesame. Nature Communications 6:8609. https://doi.org/10.1038/ncomms9609

You, F., Li, P., Kumar, S., Ragupathy, R., Li, Z., Fu, Y., and Cloutie, S. 2014. Genome-wide identification and characterization of the gene families controlling fatty acid biosynthesis in flax (Linum usitatissimum L). Journal of Proteomics and Bioinformatics 7(10):310-326. https://doi. org/10.4172/jpb.1000334 